\title{
Realms of Ritual
}





\section{Realms of Ritual}

Burgundian Ceremony

and Civic Life

in Late Medieval Ghent

PETER ARNADE

Cornell University Press

ITHACA AND LONDON 


\section{Copyright $(\mathcal{C} \mathrm{I} 996$ by Cornell University}

All rights reserved. Except for brief quotations in a review, this book, or parts thereof, must not be reproduced in any form without permission in writing from the publisher. For information, address Cornell University Press, Sage House, 5 I 2 East State Street, Ithaca, New York I4850.

First published 1996 by Cornell University Press.

\section{Library of Congress Cataloging-in-Publication Data}

Arnade, Peter J.

Realms of ritual : Burgundian ceremony and civic life in late medieval Ghent / by Peter Arnade.

p. $\mathrm{cm}$.

Includes bibliographical references and index.

ISBN 0-801 4-3098-4 (alk. paper)

I. Ghent (Belgium)-Social life and customs. 2. Rites and ceremonies-Belgium-Ghent. 3. Cities and towns, Medieval-BelgiumGhent. 4. Belgium-History-To I555. I. Title.

DH8II.G46A93 I996

$949.3^{\prime}$ I420I-dc20

Printed in the United States of America

(2) The paper in this book meets the minimum requirements of the American National Standard for Information SciencesPermanence of Paper for Printed Library Materials, ANSI Z39.48-1984. 
For Betsy

"Porque el fuego no muere"

- Pablo Neruda 
